\title{
KARAKTERISTIK LINGUISTIK DAN NONLINGUISTIK PADA PENDERITA GAGAP KRONIS
}

\author{
Tadkiroatun Musfiroh \\ FBS Universitas Negeri Yogyakarta
}

\begin{abstract}
One interesting focus in a psycholinguistic study is stuttering, a form of slip of the tongue. This research study attempts to describe linguistic and nonlinguistic characteristics of utterances by a 25-year-old woman suffering from stuttering.

The research data were collected through observations and interviews by recording and writing them down. The data analysis in the field was done by making objective notes, reflecting on them, and confirming them with relevant theories. The observation data analysis outside the field was done by classifying stuttering forms into linguistic and nonlinguistic areas, dividing them into sentence lingual units according to their constituents, marking them with lingual units, categorizing them according to the appearance of linguistic themes, and uniting linguistic and nonlinguistic themes. The interview data analysis outside the field was done by organizing the data, putting them into patterns and categories, and finding out relationships among categories.

The research findings show that the subject's stuttering is chronic. This is shown by the stuttering frequency which was over $10 \%$ during the interview and in the free conversation. Linguistic characteristics in the stuttering include (1) the repetition of vowels and consonants in the initial and medial positions, (2) the repetition of closed and open syllables, (3) the repetition of words, especially mono-syllable words, and (4) the prolongation of vowels and consonants. Nonlinguistic characteristics include (1) the mouth stiffness, (2) the lip tremble, (3) the foot stamp, (4) the movement of hands and legs to help to speak, (5) the head movement, (6) the loss of control over the speaking mechanism, and (7) the breath stops for some moments.
\end{abstract}

Key words: chronic stuttering, stuttering person, linguistic and nonlinguistic characteristics

A. Pendahuluan
1. Latar Belakang
Dalam perkembangan bahasa anak, gagap dianggap sebagai ketidaklancaran wicara yang wajar menyertai tugas pengembangan keterampilan berbicara, pengembangan kemampuan menggunakan kalimat kompleks, dan menyusun cerita. Gagap pada anak dapat dipandang sebagai kasus kecepatan otak yang melebihi alat artikulasi, khususnya lidah (Heins, 2003). Gagap umumnya menghilang begitu anak dapat mengendalikan emosi dan melakukan penyesuaian sosial. Gagap muncul lagi ketika anak mengalami "ketakutan" karena memasuki dunia baru seperti lingkungan sekolah yang lebih luas (Hurlock, 1997). Meskipun demikian, adakalanya gagap menetap beberapa saat bahkan hingga seseorang tumbuh menjadi dewasa. Gagap yang demikian dikategorikan sebagai gagap kronis dan menjadi bagian dari kelainan wicara (Ballenger, 1994).

Clark \& Clark (1977) dan Garnham (1985) mengkategorikan 
gagap ke dalam kesalahan ujaran atau speech error yang sejajar dengan dengan kasus keragu-raguan berbicara (hesitation), keseleo lidah (slips of the tongue), jeda isi (filled pause), jeda kosong (silent pause), pengulang-ulangan (repeats), koreksi (correction), dan interjeksi (interjection), kesalahan awal (false starts).

Menurut Hurlock (1997), gagap mungkin muncul pada setiap saat dalam rentang hidup seseorang. Masa yang paling rentan adalah masa-masa tahun prasekolah pada waktu anak mencoba menguasai tugas belajar berbicara dan pada waktu anak mencoba menguasai tugas belajar berbicara dan pada waktu setiap gangguan emosional mungkin mengganggu proses belajar itu. Gagap dapat saja terjadi selama beberapa tahun dan mungkin menetap.

B eberapa penelitian menunjukkan bahwa gagap lebih banyak ditemukan pada anak laki-laki daripada anak perempuan (perbandingan $4: 1$ ). Hal itu terjadi karena anak laki-laki umumnya lebih lambat dalam perkembangan sosial dan bahasa, mengalami banyak persaingan, rentan frustasi terutama dalam hal berbahasa dibanding anak perempuan. Kecemasan dan ketegangan dalam proses berkomunikasi memperburuk kegiatan berbicara anak (Schuell via Ballenger, 1994; Hwang, 2003; Fox, 2003) Dengan demikian, gagap kronis pada perempuan termasuk kasus yang jarang ditemukan.

Selain itu, gagap yang diderita oleh seseorang hingga dewasa merupakan masalah yang jarang ditemukan. Pada anak-anak, gagap memang hal yang wajar, tetapi gagap yang bertahan hingga dewasa merupakan kasus gangguan wicara yang perlu memperoleh perhatian serius. Penelusuran riwayat timbulnya gagap perlu dilakukan untuk memperoleh gambaran awal faktor pemicu dan pemacu kegagapan tersebut. Berdasarkan alasan-alasan di atas itulah maka kasus gagap menetap pada wanita menarik untuk dikaji. Terlebih lagi, permasalahan yang menjadi bagian dari studi psikolinguistik ini relatif jarang dikaji. Oleh karena itu, pengamatan yang teliti perlu dilakukan. Penelitian ini berfokus pada masalah gagap yang diderita oleh seorang wanita dewasa. Adapun masalah yang dijawab dalam penelitian ini meliputi wujud gangguan berupa karakteristik linguistik dan nonlinguistik.

\section{Tujuan Penelitian}

Penelitian ini bertujuan untuk mendeskripsikan karakteristik linguistik dan nonlinguistik gagap subjek pada saat berkomunikasi.

\section{Landasan Teori}

Gagap menurut Clark \& Clark (1977) merupakan bagian dari kesilapan tutur. Sementara Perkins (via Shine, 1997) menyebutkan bahwa "stuttering is the experience of losing control of the speech mechanism". Ini berarti, gagap berkaitan dengan hilangnya mekanisme kontrol bertutur. Gejala-gejala yang menyertai timbulnya gagap terjadi di luar kontrol pembicara. Sementara Van Riper dan Erickson (1996) mendefinisikan gagap sebagai cacat di sela-sela bicara yang tidak wajar yang ditandai oleh repetisi atau prolongasi bunyi, silabe, gaya artikulasi, atau tingkah laku menghindar dan "kejang". Ketidakwajaran jelas terlihat manakala "gerakan-gerakan" orang gagap tersebut dibandingkan dengan paralinguistik orang yang berbicara normal.

Menurut Ballenger (1997), gagap 
merupakan salah satu gangguan wicara yang bagi ahli patologi wicara merupakan fenomena yang sulit didefinisikan. Tidak ada dua penggagap yang sama dan tidak ada seorang penggagap yang dari waktu ke waktu berikutnya sama. Gagap merupakan gangguan dalam irama wicara. Beberapa ahli berusaha memerinci perilaku yang biasa ditemukan pada perilaku ikutan.

Lebih lanjut Ballenger (1994) mengatakan bahwa gagap memiliki berbagai ciri, yakni terputusnya kelancaran ekspresi verbal, terjadi repetisi dan prolongasi dari elemen linguistik disadari atau tidak, muncul aktivitas tambahan yang melibatkan organ bicara, struktur tubuh, kadang dipengaruhi oleh gangguan emosi antara bersemangat dan tegang serta gangguan yang lebih spesifik seperti ketakutan, malu, iritasi. Gagap langsung bersumber dari ekspresi yang tak terkendali dalam mekanisme bicara perifer.

Ciri lain yang menarik dari gagap adalah bahwa gagap biasanya tidak disadari. Di tengah-tengah ketergagapan, penderita merasakan "kehampaan" secara mental. Beberapa peneliti menemukan bahwa penderita gagap merasa seperti "pingsan" sebelum mereka menyadari segala sesuatunya. Mereka kehilangan kesadaran di mana mereka berada, apa yang mereka lakukan, dengan siapa mereka bicara, dan lingkungan. Subjek Cited (via Hwang, 2003) menyatakan "when I stutter, my mind would come to a kind of blank state for a second, a kind of pause. I can't feel anything and can't think". Dengan demikian, pikiran pembicara berada dalam kekosongan beberapa saat, tidak dapat merasakan dan memikirkan sesuatu. Setelah peristiwa itu berlalu, beberapa penderita merasa malu, dan bahkan merasa bersalah.

Gagap dapat diklasifikasikan menjadi tiga, yakni ringan, sedang, dan berat. Gagap ringan terjadi karena ketidaklancaran berbicara terpicu masalah perkembangan sehingga semakin berkembang. Gagap sedang merupakan gagap ringan yang tumbuh mendekati kronis, sedangkan gagap berat adalah gagap dengan kekejangan yang memiliki resiko menjadi gagap kronis (Heins, 2003).

Gagap umumnya menimpa lakilaki, atau $80 \%$ laki-laki dan $20 \%$ perempuan (Hwang, 2003; Heins, 2003; Shine, 1997) Ini berarti, kasus gagap antara laki-laki dan perempuan adalah 4 banding 1 (Ballenger, 1997). Tidak kurang dari 50 juta orang di dunia menderita gagap pada saat ini (Dodge, 2003). Heins (2003) bahkan mengatakan bahwa gagap kronis telah menimpa hampir tiga juta orang. Walaupun belum ada data yang pasti, diperkirakan gagap ditemukan lebih banyak usia prasekolah, yakni sekitar 4\% (Ballenger, 1997)

Sebenarnya, setiap orang yang gagap telah berusaha keras melancarkan ujaran, meskipun tidak selamanya berhasil. Penggagap umumnya telah berusaha mencari jalan keluar dari kegagapannya itu, meskipun belum tentu memperoleh cara terapi yang tepat Salah satu strategi berbicara yang diterapkan oleh penggagap adalah menghindar. Mereka berusaha menghindari kata-kata yang sulit diucapkan dan menggantikannya dengan kata-kata-kata yang mirip (Hwang, 2003).

Gagap umumnya dimulai pada usia 2 hingga 5 tahun (Adams, 2003). Peter dan Starkweather (1990) merunut perkembangan gagap di sepanjang 
rentang kehidupan, dan membaginya ke dalam lima fase.

\begin{tabular}{|c|l|}
\hline FASE GAGAP & \multicolumn{1}{|c|}{ CIRI-CIRI } \\
\hline Fase I(2-6 tahun) & $\begin{array}{l}\text { Muncul pertama, mempengaruhi perkembangan } \\
\text { kepercayaan diri anak, tanggapan negatif lingkungan } \\
\text { bisa memerarah kondisi gagap }\end{array}$ \\
\hline Fase II (6-12 tahun) & $\begin{array}{l}\text { Anak dapat mengontrol gerak wicara, tetapi bermasalah } \\
\text { dengan keliatan otot. Pengaruh teman sebaya sangat } \\
\text { besar: inferior. }\end{array}$ \\
\hline Fase III (12-17 tahun) & $\begin{array}{l}\text { Kasus gagap menurun, jika masih muncul biasanya } \\
\text { cenerung menetap, Penderita kehilangan kepercayaan } \\
\text { diri dan menumpukan kegagalan pada gagap, mungkin } \\
\text { kehiangan masa keromantisan }\end{array}$ \\
\hline Fase IV (18-30 tahun) & $\begin{array}{l}\text { Fase mantap gagap, punya trik-trik menghadapi waktu- } \\
\text { waktu sulit. Dorongan orang terdekat dapat membantu } \\
\text { perasaan terisolasi }\end{array}$ \\
\hline Fase V $(30>)$ & $\begin{array}{l}\text { Fase stabil : stabil emosional dan sosial. Kualitas gagap } \\
\text { menurun. Trik-trik mulai dilepaskan }\end{array}$ \\
\hline
\end{tabular}

Wexler (1996) membagi proses gagap ke dalam tiga tingkat, yakni tingkat oral, tingkat laringal, dan tingkat respirator (pernapasan). Pada tingkat oral, penggagap mengulang satu atau lebih unit bunyi, bagian kata, kata, atau frase. Repetisi mungkin ringan mungkin juga berat. Struktur lisan mungkin muncul bersama-sama kesulitan artikulasi atau bloking serta ketidakmampuan mengeluarkan suara pada jeda tegang. Artikulatori atau tekanan udara yang berlebihan mempengaruhi kualitas keeksplosifan konsonan seperti "B!!!ut". Ketegangan mungkin dapat mengakibatkan tremor (gemetaran). Pada tingkat ini, dapat saja muncul prolongasi.

Pada tingkat laringal, penggagap ti dak dapat memulai atau mempertahankan penyuaraan. Terdapat pemblokiran melalui hambatan pada pita suara baik dalam posisi terbuka maupun posisi tertutup. Tidak ada suara yang keluar dengan jeda yang disertai dengan jeda ketegangan. Sebaliknya, udara yang disuarakan mungkin terdengar melekat pada bunyi bahasa seperti "hhhopen". Kekejangan laringal dilibatkan untuk gejala fonatori. Riset menunjukkan bahwa selama gagap terdapat penurunan timbal balik antara otot agonis dan antagonis pada laring dan tingkat aktivitas dari otot laringan instrinsik yang terlalu berlebihan. Selain itu ditemukan juga pola aktivasi pada orang dewasa melalui elektromigram (EMG).

Pada tingkat respirasi, keluarnya udara (volume cadangan terakhir pada wicara), terengah-engah atau megapmegap biasa terjadi. Tekanan udara yang berlebihan mungkin menambah keeksplosifan dan kebersuaraan ujaran. 
Gagap merupakan gangguan bicara yang paling sulit ditelusuri penyebabnya. Gagap atau stuttering bukanlah tingkah laku yang dipelajari. Beberapa ahli menyimpulkan bahwa gagap bukan kondisi nervous, bukan masalah psikologis, bukan masalah emosional, dan bukan pula masalah yang disebabkan oleh tekanan kekerasan orang tua atau tekanan lingkungan. Gagap tidak diakibatkan oleh reaksi orang tua terhadap tuturan anak seperti hentian maupun keraguraguan dalam kalimat atau sebelum mulai berbicara; interjeksi seperti " $u h^{\prime}$, "um", "aduh", "ya kan" atau revisi kata seperti "oh, bukan..bukan", "maksud saya", atau repetisi "kita telah...(berhenti). Kita telah bertemu"(Shine, 1997; Adams, 2002).

Riset yang diadakan di Yale University menghasilkan suatu dasar genetis umum tentang gagap, faktorfaktor organik yang berinteraksi dengan faktor lingkungan secara kompleks. Anak-anak dengan kecenderungan organik gangguan kelancaran, yang berriwayat gagap dalam keluarga maupun tidak, faktor lingkungan dan perkembangan mungkin saja menimbulkan, memburuk, dan mempertahankan masalah gagap. Di bawah tekanan, waktu untuk mengkoordinasi 100 otot lebih dari sistem ujaran menimbulkan kesulitan tersendiri bagi penggagap. Sebaliknya, meskipun neuromuskuler (yang mudah terluka) dari sistem ujaran mengalami gangguan, mereka masih dapat berbicara dengan lancar apabila berada dalam kondisi tanpa tekanan dan kondisi-kondisi lain yang memfasilitasi koordinasi otot-otot wicara. Tekanan komunikasi yang berlebih (kecepatan bicara, interupsi, ketepatan pelafalan), kegembiraan, ketakutan akan kegagapan, atau tekanan lingkungan lainnya, memicu dan memperburuk ketidaklancaran pada anak yang memiliki sistem wicara yang mudah terluka. Meskipun latar belakang timbulnya gagap kadang dapat diprediksikan, tapi tidak selamanya demikian. Kembar, misalnya, memiliki kemungkinan gagap lebih besar dari yang tidak. Pengkondisian dan faktor pembelajaran lain memunculkan dan mempertahankan permasalahan (Wexler, 1996).

Gagap， seperti halnya ketidakjelasan bicara atau slurring dan kebingungan bicara atau cluttering, merupakan gangguan pengucapan yang serius. Walaupun mula-mula muncul pada masa-masa awal pemerolehan bahasa, gagap berbeda dengan fenomena cadel dan keragu-raguan bicara, hesitasi atau hesitations. Gagap, dalam hal ini lebih berat dari cadel dan hesitasi. Pertama, gagap tidak disebabkan oleh kesalahan belajar tetapi oleh cacat yang terjadi dalam mekanisme suara atau oleh ketegangan emosional yang menetap. Kedua, gagap tidak dapat dibetulkan dengan mempelajari pengucapan yang betul. Ketiga, gagap hanya dapat diatasi dengan menghilangkan faktor penyebabnya (Hurlock, 1997).

Terdapat tiga faktor yang dicurigai sebagai penyebab timbulnya gagap. Pertama adalah faktor genetis dan neuropsikologis. Terdapat beberapa bukti gagap dimulai dalam ranah keluarga dan terjadi perbedaan proses hemisfer yang rumit baik penurunan kapasitas hemisfer untuk perkembangan linguistik maupun penundaan waktu pemrosesan. Meskipun demikian, tidak ada bukti bahwa gagap diwariskan (inherited) atau disebabkan oleh gangguan neurologis. Kedua adalah

Litera, Volume 3, Nomor 2, Juli 2004 
faktor belajar dan lingkungan. Teori ini memfokuskan diri pada lingkungan belajar anak dan kesempatan untuk belajar berbicara. Walaupun ada bukti kaitan antara lingkungan fisik dan gagap, tetapi itu bersifat sugestif dan kurang meyakinkan. Ketiga adalah faktor emosional dan psikologis. Pada masa lalu, gagap dipandang sebagai kekacauan emosional atau kegelisahan. Saat ini, emosi-emosi negatif yang berkaitan dengan gagap dianggap sebagai sesuatu yang melekat pada diri seorang penderita gagap daripada sebagai penyebab. Meskipun demikian, para ahli yakin bahwa ada kaitan antara emosi dan psikologi anak dan menjadijadinya kegagapan (Adams, 2002).

Walaupun beberapa lembaga peduli gagap di berbagai belahan bumi tidak dapat memastikan faktor penyebab gagap yang utama, sebagian para ahli memfokuskan analisis mereka pada unsur diskoordinasi otak, khususnya hemisfer kiri. Riset yang dilakukan Joseph LeDoux menunjukkan bahwa amigdala (amygdalae) merupakan komponen utama perputaran otak termasuk mediasi kondisi klasikal, pengulangan, kebawahsadaran, respon refleks untuk mengkondisikan stimulasi pada mamalia, termasuk manusia. Amigdala merupakan struktur bilateral yang berkaitan dengan"sistem limbik" pada dasar telensepalon, yang disebut sebagai "papez circuit" yang memodulasi agresivitas dan ketakutan. Di dalam sistem limbik terdapat juga hipokampus, korteks singulat, beberapa nucleu talamus, septum, dan badan mamilari pada dasar hipotalamus. Aksi karakteristik dari lingkaran ini mendesak ketika struktur sistem limbik ditunjukkan sebagai mediator reaktif yang masuk akal, gagap kronis pada manusia. (the characteristic actions of this circuit are compelling when these structures are viewed as possible mediators of reactive, chronic stuttering behavior in humans).

Apabila gagap dapat dibatasi pada hesitasi dan repetisi normal yang khas pada masa perkembangan, gagap akan menghilang secara spontan dan bantuan klinik secara langsung jarang diperlukan. Akan tetapi apabila gagap berkembang ke arah yang lebih berat, disertai ketegangan, kecemasan, muka dan tubuh menyeringai, menghindari kegiatan berbicara, muncul perasaan frustasi dan bersalah, maka masalahnya menjadi masalah klinis. Obsevasi klinis menunjukkan bahwa perilaku tersebut terjadi pada penderita gagap tahap lanjut (Ballenger, 1997).

Hampir semua penggagap mempunyai masa yang relatif lepas dari keragu-raguan, pengulangan, terhenti, dan prolongasi. Si penggagap dapat menyanyi atau berkata-kata tanpa gangguan aliran wicara, dan biasanya tidak mengalami kesulitan pada waktu berbicara keras kepada dirinya sendiri atau kepada binatang peliharaan. Van Riper berpendapat bahwa "makin gagap seseorang, makin takut ia pada kata-kata dan situasi tertentu. Semakin takut seseorang, semakin gagap ia. Semakin berusaha untuk tidak gagap, semakin banyak kesalahan yang dibuat olehnya, dan ketakutan pun makin bertambah"(via Ballenger, 1994).

\section{B. Metode Penelitian}

Penelitian ini merupakan penelitian studi kasus. Subjek penelitian tunggal, perempuan, berinisial A.F, usia 25 tahun. Subjek menderita gagap sejak usia 3 tahun dan menetap hingga sekarang. Subjek merupakan anak bungsu. Ia mempunyai saudara kembar yang tidak gagap, laki-laki, dan memiliki prestasi akademik lebih baik. Di dalam 
keluarganya, saat ini, subjek adalah satusatunya penderita gagap. Untuk memenuhi etika dalam penelitian (Mussen, 1988), data yang terlalu pribadi sengaja tidak ditampilkan.

Data penelitian dikumpulkan dengan dua metode, yakni metode wawancara dan observasi. Wawancara dilakukan secara mendalam untuk mengungkap latar belakang timbulnya gagap menyangkut sejarah masa kanakkanak, awal kemunculan gagap, perasaan, dan hal-hal khusus yang dirasakan subjek saat berbicara. Wawancara juga dilakukan terhadap keluarga subjek, yakni ibu dan saudara kembar subjek. Wawancara dilakukan secara informal, tak terstruktur, dan bersifat terbuka (Moleong, 2002). Selain wawancara, dilakukan juga observasi, yakni mengamati secara seksama aktivitas subjek ketika berinteraksi secara verbal dengan orang-orang di sekelilingnya. Observasi ini dilakukan guna mengungkap wujud kegagapan dan gejala munculnya gagap pada diri subjek. Observasi juga dilakukan dengan menyimak perilaku linguistik subjek dengan teknik simak libat cakap dan tanlibat cakap (Sudaryanto, 1993). Teknik lanjut yang digunakan adalah teknik rekam dan catat. Teknik rekam digunakan untuk merekam tuturan subjek, dan teknik catat digunakan untuk mencatat gejala kegagapan, baik linguistik maupun nonlinguistik yang dapat teramati pada saat subjek menghasilkan tuturan. Hasil rekaman ditranskripsi secara ortografis. Pada satuan tertentu yang melalui teknik pemarkahan dicurigai sebagai wujud kegagapan, dilakukan transkripsi sistematis. Pengambilan data dilakukan selama empat bulan, yakni pada bulan Mei hingga Agustus 2003. Data diambil dengan memperhatikan berbagai aktivitas verbal seperti menjawab pertanyaan, bertanya, menirukan, menyanyi, memberikan paparan.

Analisis data dilakukan melalui dua tahap, yakni analisis data lapangan dan analisis data setelah meninggalkan lapangan (lihat Bogdan via Muhadjir, 1991). Analisis data lapangan dilakukan dengan (1) membuat catatan objektif dari data catat dan rekam, yakni data-data yang menyangkut wujud ketergagapan dan gejala-gejala yang tersimak dan teramati seperti gerak tangan, ekspresi wajah, dan ketidaklancaran berbicara, (2) menuliskan catatan reflektif yang muncul dari catatan objektif, dan (3) meninjau kembali atau konfirmasi kepustakaan yang relevan. Analisis pasca lapangan dilakukan dengan (1) memisahkan wujud gagap ke dalam wilayah linguistik dan nonlinguistik (2) membagi wujud gagap linguistik ke dalam satuan lingual kalimat berdasarkan konstituennya, (3) menandai wujud gangguan dalam satuan lingual, (4) mengkategorikan wujud gangguan bahasanya berdasarkan tema-tema kemunculan secara linguistik, (5) menyatukan kembali tema-tema linguistik dan nonlinguistik. Terhadap hasil wawancana, analisis pasca lapangan dilakukan dengan mengorganisasi data, mengurutkan data ke dalam pola-pola dan kategori-kategori, menemukan hubungan antarkategori.

Keabsahan data diperoleh melalui kriteria kredibilitas. Teknik yang digunakan untuk itu adalah ketekunan pengamatan dan trianggulasi. Trianggulasi yang dipakai adalah (1) trianggulasi sumber yakni membandingkan data hasil pengamatan dengan data hasil wawancara, membandingkan apa yang dikatakan subjek dengan apa yang dikatakan 
sumber lain yakni ibu dan saudara kembar subjek, (2) trianggulasi metode yakni pengumpulan data ganda, dan (3) trianggulasi teori yakni membandingkan data dengan teori yang telah ada (Moleong, 2002).

\section{Hasil Penelitian dan Pembahasan 1. Hasil Penelitian}

Sesuai dengan tujuan penelitian, berikut ini disajikan hasil penelitian meliputi karakteristik linguistik dan karakteristik nonlinguistik yang terdapat pada kegagapan subjek.

\section{a. Karakteristik Linguistik}

Karakteristik linguistik yang ditemukan pada gagap subjek meliputi repetisi (pengulangan) dan prolongasi (pemanjangan bunyi). Repetisi yang ditemukan meliputi tiga tataran, yakni bunyi, silabe, dan kata. Dari hasil ini diketahui bahwa karakteristik linguistik yang muncul memiliki frekuensi yang relatif tinggi, yakni antara $11 \%$ hingga $24 \%$ dalam berbagai aktivitas verbal.

\section{1) Repetisi Tataran Bunyi}

Repetisi tataran bunyi terjadi pada semua vokal, terutama [a] dan [i] seperti [a-a-aku] dan bunyi [?], baik sebagai jeda isi (filled pause) seperti dalam e..e.. maupun sebagai bunyi awal seperti dalam [?-?-?ma?ku]. Repetisi vokal [i], [u], [U], [o], dan [O] relatif jarang ditemukan.

Selain itu, ditemukan juga repetisi konsonan baik konsonan bersuara seperti [b], [d], [j], [g], dan nasal serta konsonan tak bersuara seperti $[\mathrm{t}],[\mathrm{k}]$, dan [s]. Repetisi konsonan ditemukan dalam posisi penultima dan prapenulitima pada posisi inisial dan final suku [?-?-??m??ña] maupun final seperti pada [s?k-k-kali]. Dalam hal ini, repetisi konsonan cenderung disertai dengan kekejangan. Pada saat mengulang konsonan, bibir subjek bergetar dan matanya mengerjapngerjap. Terlihat upaya yang cukup keras untuk melafalkan konsonan tertentu, seperti /d/, /m/, dan /g/. Pengulangan terjadi lebih dari tiga kali sehingga dikategorikan sebagai repetisi yang menyertai gagap kronis. Repetisi vokal dan konsonan dalam ambilan 400 kata pertama menunjukkan frekuensi berikut ini. 
Tabel 1. Repetisi Konsonan pada Gagap Subjek

\begin{tabular}{|c|c|c|c|c|c|c|c|}
\hline Cara & Bilabial & $\begin{array}{l}\text { Labio } \\
\text { dental }\end{array}$ & Dental & Alveolar & Palatal & Velar & Glotal \\
\hline $\begin{array}{l}\text { Tak bersuara } \\
\text { Hambat } \\
\text { Bersuara }\end{array}$ & $\begin{array}{l}\mathrm{p}(4) \text { p-p-pirl? } \\
\mathrm{b}(2) \mathrm{b} \text {-b-bila? }\end{array}$ & & $\begin{array}{c}t(4) \text { it-t-tu } \\
d\end{array}$ & $\begin{array}{l}\quad(4) \\
\text { b rpi - - } \\
\text { ato }\end{array}$ & $\begin{array}{c}c \\
\text { j-j-jalan }\end{array}$ & $\begin{array}{l}\text { k (8) s k-k-k-kal } \\
j(2) \\
g(2) \\
\text { bag-g-gimana }\end{array}$ & $?$ \\
\hline $\begin{array}{l}\text { Tak bersura } \\
\text { Frikatif } \\
\text { Bersuara }\end{array}$ & & f & $\begin{array}{c}\text { s (3) } \\
\text { s-s- } \\
\text { sadar } \\
z \\
\end{array}$ & & & $X$ & h \\
\hline $\begin{array}{l}\text { Nasal } \\
\text { Bersuara }\end{array}$ & $\begin{array}{l}\quad \mathrm{m}(4) \\
\mathrm{m} \text { m-m-m } \\
\text { mbaca }\end{array}$ & & & $\begin{array}{c}\text { n (3) } \\
\text { n-n-n- } \\
\text { namaña }\end{array}$ & $\tilde{\mathbf{n}}$ & $\begin{array}{l}n(3) \\
\text { n-n-n- } \\
\text { nomonña }\end{array}$ & \\
\hline $\begin{array}{l}\text { Getarl } \\
\text { Bersuara }\end{array}$ & & & & $\begin{array}{c}r(2) \\
\text { b r-r-rat }\end{array}$ & & & \\
\hline $\begin{array}{l}\text { Lateral } \\
\text { Bersuara }\end{array}$ & & & & 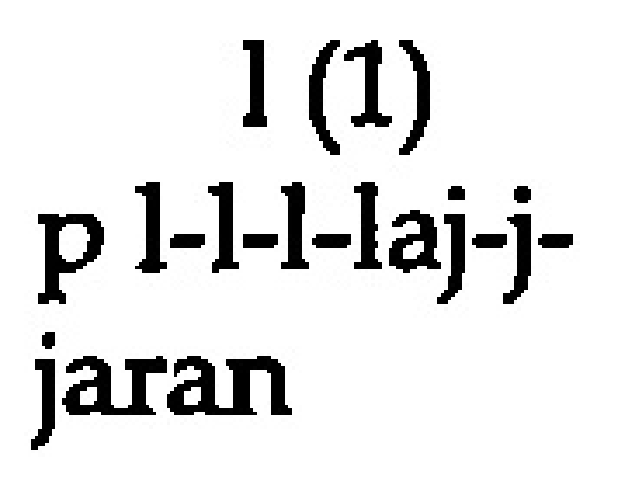 & & . & \\
\hline $\begin{array}{l}\text { Semivokal } \\
\text { Bersuara }\end{array}$ & $\begin{array}{c}\text { w (2) } \\
\text { w-w-waktu }\end{array}$ & & & & $\begin{array}{l}\text { y (1) } \\
\text { say-y- } \\
\text { ya }\end{array}$ & . & \\
\hline
\end{tabular}

Dari data diketahui bahwa konsonan hambat dan nasal mengalami frekuensi repetisi lebih tinggi dibanding dengan konsonan lain. Kemunculan repetisi ini bahkan lebih sering daripada kemunculan semivokal bilabial yang menurut subjek sulit diucapkan. Meskipun demikian, tidak semua konsonan hambat dan nasal ditemukan mengalami pengulangan.

Pengulangan juga terjadi pada hampir semua vokal. Vokal /a/ mengalami pengulangan paling tinggi, yakni 15 kali, kemudian /i/ sebanyak 2, dan vokal /u/, /o/, /?/ masingmasing 1 kali. Pengulangan vokal /e/ tidak ditemukan dalam data tersebut.

\section{2) Repetisi Tataran Silabe}

Selain pengulangan vokal dan konsonan, ditemukan juga pengulangan suku kata. Repetisi jenis ini ditemukan pada suku kata nonultima dalam posisi terbuka. Dengan kata lain, repetisi suku kata muncul ketika subjek berusaha mengucapkan kata-kata yang bersuku a w a 1 t e r b u k a, s e per $\mathrm{i}$ "pa..pa..kekekecil", dan "sususulit". Repetisi bagian kata ini memiliki frekuensi kemunculan yang relatif tinggi. Tingkat pengulangannya umumnya lebih dari dua kali, seperti "rarararassssanya". Pengucapan semacam ini biasanya diakhiri dengan penekanan (dengan suara keras dan menghentak) suku yang diulang 
tersebut. Setelah itu, subjek dapat mengucapkan beberapa kata dengan lancar. Pengulangan suku kata terbuka ditemukan pada posisi prapenultima dan penultima kata, dan jarang yang ditemukan pada suku kata ultima.

Pengulangan suku kata tertutup relatif jarang ditemukan. Hanya ditemukan pengulangan suku kata tertutup pada suku kata nonultima, yakni penultima seperti pada "sudsudah" dan suku kata prapenultima seperti pada "disor-soraki". Repetisi suku kata ultima tidak ditemukan. Pengulangan suku kata umumnya memiliki frekuensi dua kali dalam satu kali repetisi. Jarang ditemukan pengulangan suku kata lebih dari itu.

\section{3) Repetisi Kata}

Selain pengulangan bunyi dan suku kata, ditemukan juga pengulangan kata. Pengulangan tipe ini relatif jarang ditemukan, itu pun umumnya berupa kata-kata bersuku tunggal seperti kata ning 'di', pas 'waktu', bar 'selesai', dan mau 'tadi'. Pengulangan ini berfungsi sebagai pengisi atau filled pause.

Pengulangan dapat terjadi dalam kadar ringan maupun berat. Dalam kadar ringan repetisi terjadi dalam bentuk pengulangan suku kata 2-3 kali dan tidak disertai dengan ketegangan pada daerah artikulasi. Dalam kadar berat, pengulangan terjadi pada bunyi yang diikuti bloking tanpa suara (hanya mulut yang bergerak-gerak seperti mau berkata-kata). Dalam kadar yang sangat berat, gejala tersebut disertai dengan gerakan mengepalkan tangan, menghentakkan kaki, menyerua, dan bahkan mengerjap-ngerjapkan mata. Semuanya berfungsi sebagai pendorong keluarnya suara.

\section{4) Prolongasi}

Prolongasi adalah pemanjangan fonem, baik konsonan maupun vokal secara tidak wajar (akibat perjuangan melafalkan). Berdasarkan pengamatan diketahui bahwa prolongasi fonem yang dialami subjek berupa vokal yang berada pada posisi inisial dan final pada suku nonultima seperti "aaaa(tersendat)dik", "maaaa(tersendat)kin" dan konsonan pada posisi inisial seperti pada "bagggg(tersendat)gaimana" dan adddd(tersendat)da" Prolongasi pada posisi akhir tidak ditemukan. Diketahui juga bahwa prolongasi cenderung terjadi pada fonem-fonem tertentu.

Prolongasi vokal /a/ dan /i/ memiliki frekuensi tinggi. Pada prolongasi vokal /a/ cenderung disertai dengan ketersendatan (menahan napas), seperti "aaaa(tersendat) dik". Ketersendatan yang menyertai prolongasi vokal /a/ tersebut diikuti oleh hentakan, barulah setelah itu suku kata berikutnya terucap dengan lancar.

Hasil analisis menunjukkan bahwa konsonan tertentu, seperti /d/, $/ \mathrm{p} /, / \mathrm{k} /$ memiliki frekuensi prolongasi yang cukup tinggi. Konsonan hambat, baik bersuara maupun tansuara, cenderung dipanjangkan. Prolongasi tersebut seringkali disertai ketersendatan dan diakhiri dengan interjeksi. Pada saat terjadi prolongasi, mulut subjek terbuka dan ada kalanya disertai getaran. Prolongasi berakhir setelah subjek membuat interjeksi sehingga terkesan muncul "blok". Dalam beberapa hal, prolongasi juga mengesankan keragu-raguan (hesitasi).

\section{b. Karakteristik Nonlinguistik}

Hal yang menarik dari gagap subjek adalah tidak ditemukannya strategi menghindar. Beberapa kata yang sulit diucapkan tidak dihindari. 
Menurut subjek, ia tidak menghindari kata-kata tertentu (umumnya mengandung konsonan hambat dan nasal), karena meyakini akan berhasil mengucapkannya. Apabila dalam tuturan terdapat banyak bunyi hambat dan nasal, ketidaklancaran akan cenderung meningkat.

Sepertinya, nnngomongnya itu sulit sekkkkali. Ya...pasti kalau deg-deg gitu, aduh ! Gggg(tersendat)gimana nggomongnya gitu. Pikirannya langsung aku nggak bisa ngomong, pasti gitu...Iya..grogi gitu, tho mbak. Rararasanya grogi ber-r-rat gitu, lho. Piye ki, ya..piye ki ya, gitu Apppa lagi kkkalau langsung lihat gitu. .

Walaupun menyadari bahwa mengucapkan kata-kata yang mengandung konsonan-konsonan hambat dan nasal cenderung menimbulkan ketergagapan, subjek tidak mempedulikannya. Wawancara menunjukkan bahwa subjek tidak merasa perlu menghindari kata-kata tertentu.

Berdasarkan observasi diketahui bahwa karakteristik nonlinguistik yang muncul adalah kekejangan pada mulut, getaran pada bibir, mata terbelalak, dan mengerjap-ngerjap, gerakan-gerakan tangan untuk menguatkan, bahkan hentakan kaki pada saat interjeksi dilakukan. Gerakan-gerakan kepala kadang dilakukan ketika subjek merasa gagal mengucapkan kata-kata tertentu.

Enggak! Itttu terjadi kakakaka.. (mata membeliak, berhenti)lau dihati

Itu merasa ttertekkkaan gitu, lho....

W w w a k $\mathrm{t} u$ s a y y a mmm..apa..wwwawan(tersend at dan tegang)carai ya, mbak. Itu sulit banget.

Pas teggg (tersendat, menghentakkan kaki) ah! (menumpahkan kekesalan)

(catatan : subjek gagal mengucapkan kata tegang)

Karakteristik nonlinguistik seperti mata terbeliak, berhenti mengehela napas, tersendat dan menunjukkan ketegangan, menghentakkan kaki, dan ekspresi kemarahan muncul beberapa kali dalam satu kali wawancara. Pada pertengahan wawancara, bahkan, kemunculannya relatif sering. Pengamatan menunjukkan bahwa pada saat tersendat dan emosi, muncul kekejangan otot kerongkongan dan diafragma. Gangguan pernapasan, yakni berhentinya proses menghirup dan mengeluarkan napas dalam beberapa saat pun terjadi. Hal ini mirip dengan kondisi ketika seseorang berada dalam ketakutan yang berakibat pada hilangnya kata-kata. Apabila ketegangan otot berlalu, gagap berhenti dengan sendirinya, dan subjek mengucapkan kata-kata seperti biasa.

Gejala fisik yang ditemukan oleh peneliti terdahulu (pada penderita lain) juga ditemukan pada diri subjek, yakni napas yang terhenti beberapa saat, gejala hilangnya kontrol sementara, dan gerakan pengulangan untuk menghimpun kekuatan berbicara. Dalam situasi khusus, misalnya terlalu bersemangat, gagap juga muncul melalui gejala prolongasi yang disertai getaran bibir. Gelengan kepala dan kepalan tangan juga muncul pada saat subjek berbicara penuh semangat. Meskipun demikian, subjek tidak menyadari hal itu.

Wah, kkk (tersendat) kalau pas pet gitu ya nggak sadar. Tahutahu pppet g-g-gitu! 
"Kakakalau pas "a..a...a" gitu, mulutnya kak-k-ku, suaranya nn-ndak mau keeeeluar, nyumpel 'menyumbat' di $t-t$ tenggorokan. Ndak biiiisa ngend-dalikan mulut, Mulutnya g-g-gemeter. Ya wis 'sudah' gitu itu trus baaaru bisa ng-ng-ngomong lagi. Terus gitu, terus gitu.

Ini berarti, gagap, baik dalam bentuk pengulangan, pemanjangan, penghentian maupun pematahan, muncul di luar kendali dan rencana. Sistem produksi ujaran bereaksi di luar perencanaan. Bentuk yang keluar, dalam proses eksekusi, tidak dapat dikendalikan.

\section{Pembahasan}

Dari data diketahui bahwa gagap yang diderita subjek tergolong gagap kronis. Hal ini ditunjukkan oleh kestabilan data kegagapan, baik data linguistik maupun nonlinguistik dari waktu ke waktu selama empat bulan. Kekonstanan data yang dapat dikategorikan sebagai karakteristik linguistik dan frekuensi kemunculannya berupa repetisi vokal dan konsonan, repetisi suku kata, kata, dan prolongasi vokal dan konsonan yang relatif tinggi menunjukkan bahwa ketidaklancaran wicara yang diderita subjek dikategorikan sebagai gangguan berbicara yang serius. Oleh karena gangguan itu berupa gangguan irama dan ketidaklancaran pelafalan, maka gangguan itu dikategorikan sebagai gagap kronis atau gagap sekunder (Balengger1994).

Repetisi yang relatif tinggi, berkisar antara $11 \%$ hingga $24 \%$, menunjukkan tingkatan gagap oral yang berat. Pada subjek, proses oral ini disertai ketidakmampuan mengeluarkan suara secara lancar sehingga dalam jeda tegang, bunyibunyi itu diulang, yang apabila dihitung melebihi tiga hitungan. Keinginan untuk terus mengucapkan menimbulkan tekanan udara yang berlebihan sehingga mempengaruhi kualitas keeksplosifan konsonan sehingga adakalanya muncul interjeksi.

Karakteristik prolongasi, terutama prolongasi konsonan, yang relatif tinggi menunjukkan kaitan fisik pada daerah kerongkongan dan sistem pernapasan pada umumnya. Keterhentian pada prolongasi dan kegagalan subjek untuk memulai atau mempertahankan pengucapan fonem selanjutnya mengindikasikan gagalnya proses respirasi dan laringasi. Ini berarti, gagap telah sampai pada tingat laringal dan respirasi (lihat Wexler, 1996).

Kemunculan repetisi dan prolongasi konsonan hambat dalam frekuensi yang cukup tinggi menunjukkan bahwa pengucapan fonem yang diucapkan dengan menahan udara dari paru-paru mengalami peningkatan hambatan dalam diri subjek. Konsonan-konsonan tersebut, mungkin bersifat membangkitkan keterhambatan pelafalan. Demikian juga konsonan nasal, keterhambatan udara dari paru-paru meningkat dalam proses eksekusi.

Tingginya repetisi dan prolongasi vokal /a/ dan /i/ menunjukkan bahwa pengucapan vokal tengah rendah yang diucapkan dengan lidah bagian tengah agak merata dan mulut terbuka tersebut cukup sulit. Posisi mulut terbuka memicu prolongasi. Bahkan karena prolongasi pada vokal itu disertai munculnya bunyi hambat glotal, kekejangan pada daerah mulut pun muncul. 
Selain itu, hilangnya kesadaran secara mendadak ( $\mathrm{Jw}$. Pet), ketidaktahuan subjek terhadap reaksi lawan bicara, terhentinya proses perencanaan dan eksekusi produksi menunjukkan bahwa koordinasi mekanisme motorik wicara terhenti pada saat itu. Hal ini merupakan tandatanda gagap sekunder yang hanya dimiliki oleh penderita gagap kronis.

Kemunculan pemblokiran melalui hambatan pada pita suara baik dalam posisi terbuka maupun tertutup, mengakibatkan bunyi-bunyi tidak terucap, berhenti, dan mulu subjek menganga dan bergetar beberapa saat. Tidak ada bunyi bahasa yang keluar. $\mathrm{Hal}$ ini sesuai dengan hasil riset para ahli bahwa selama gagap terjadi penurunan timbal balik antara otot agonis dan antagonis pada laring dan terjadi aktivitas otot laringal intrinsik yang berlebihan. Pola aktivasi tersebut dapat dipantai melalui elektromogram (EMG).

Riwayat gagap subjek juga menunjukkan bahwa kekronisan gagap subjek merupakan suatu proses yang panjang. Gagap mengalami proses peningkatan, mulai sejak kemunculannya (usia 3 tahun) hingga remaja dan dewasa awal. Peningkatan itu dipengaruhi oleh berbagai faktor. Pada fase awal, subjek justru mengalami penyangatan (yang saudara kembarnya justru sembuh) karena munculnya tuntutan membaca, sesuatu yang belum bisa dilakukan subjek pada waktu itu. Pada tahun kedua dan ketiga setelah proses pengkronisan terjadi, subjek menderita kekejangan, prolongasi yang relatif rapat, dan hentian tersedak. Hal ini menunjukkan bahwa gagap kronis subjek terjadi tahap demi tahap (Heins, 2003).Proses terbentuknya gagap kronis juga dapat diprediksikan sebagai efek kembar dan pengkondisian dan faktor belajar. Sebagaimana dikemukakan Wexler (1996), kembar memiliki kemungkinan gagap daripada yang tidak. Demikian juga keteganganketegangan dan rasa marah yang berlangsung. bertahun-tahun. Sebagaimana dikemukakan subjek, prestasi saudara kembarnya telah memicu rasa minder dan tidak mampu. Subjek merasa kehilangan moment untuk menerima perhatian dari lingkungannya. Fakta ini memicu kewaspadaaan dan rasa khawatir yang berakumulasi selama bertahun-tahun. Hal ini mempengaruhi kerja amigdala.

Riset yang dilakukan Joseph LeDaux menunjukkan bahwa amigdala merupakan komponen utama perputaran otak termasuk mediasi kondisi klasikal, pengulangan, kebawahsadaran, respon refleks untuk mengkondisikan stimulasi pada mamalia, termasuk manusia. Amigdala merupakan struktur bilateral yang berkaitan dengan "sistem limbik" pada dasar telensepalon, yang disebut sebagai "papez circuit" yang memodulasi agresivitas dan ketakutan. Di dalam sistem limbik ini terdapat juga hipokampus, korteks singulat, beberapa nucleu talamus, septum, dan badan mamilari pada dasar hipokampus. Lebih lanjut LeDoux mengatakan "the characteristic actions of this circuit are compelling when these structures are viewed as possible mediators of reactive, chronic stuttering behavior in humans" (Aksi karakteristik dari lingkaran ini mendesak ketika struktur sistem limbik ditunjukkan sebagai mediator reaktif yang masuk akal, gagap kronis pada manusia) (via Hall, 2003)

Selain itu, gagap subjek pun merupakan akibat dari tugas belajar, terutama tugas membaca nyaring. Ini pun sesuai dengan pandangan Wexler 
tentang pemicu gagap (lihat Wexler 1996). Kemampuan cara pandang visual yang dipaksakan untuk memasuki tahap penafsiran simbol linguistik merupakan tugas yang berat bagi anak (Amstrong, 2003). Hal ini pun dapat diinterpretasikan sebagai terhambatnya proses adaptasi sosial dan psikologis dari kultur bermain ke kultur bersekolah secara formal. Subjek yang seharusnya masih berada di TK dihadapkan pada tugas bersekolah yang menggunakan pendekatan akademik. Pengakuan subjek menunjukkan bahwa tugas-tugas sekolah pada masa-masa SD awal merupakan tugas yang terberat, dan hal inilah yang dapat ditengarai sebagai faktor pemerparah gagap pada subjek. Hal ini sejalan dengan pendapat Heins (2003), bahwa lingkungan memainkan peran penting dalam gagap seseorang, terutama tekanan dan Hurlock (1997:198) bahwa anak sedang berusaha menguasai tugas belajar berbicara dan setiap gangguan emosional akan menganggu proses belajar tersebut.

Penelusuran lebih lanjut menunjukkan bahwa gagap subjek juga disebabkan oleh kegugupan dan gangguan emosional akibat tugas belajar bahasa Indonesia pada awal masuk sekolah. Hal ini menyulitkan subjek, terutama karena penguasaan bahasa Indonesia subjek belum cukup baik untuk mengemban tugas-tugas tersebut. Fenomena ini sejalan dengan temuan Hurlock (1997:201) bahwa tugas belajar bahasa kedua dapat menimbulkan kesalahan bicara pada anak (yang justru tidak jarang ditemukan pada anak b i l ingua l). A k ibat $\mathrm{d}$ a $\mathrm{ri}$ kekurangmampuan berbicara dapat memicu timbulnya gagap.

Hentian yang mendadak, berhentinya proses berpikir (yang oleh subjek dikatakan sebagai "pet-ilang"), menunjukkan bahwa gagap juga dipicu oleh proses perencanaan (planning). Pada orang normal, proses ini akan dianggap sebagai lupa. Pada subjek, hal itu dianggap sebagai bagian dari gagap. Hal ini mengindakasikan adanya proses neurologis yang mempengaruhi proses psikologis dan fisiologis pada diri subjek. Sayangnya hingga saat ini pemeriksanaan neurologis belum dilakukan.

Usaha penyembuhan yang dilakukan menunjukkan bahwa gagap subjek tidak tertangani secara baik. Faktor pencetus gagap tidak terdeteksi dalam waktu yang cukup lama. Faktor psikis seperti ketakutan, ketegangan, dan ketidakberdayaan yang terkompensasi melalui sikap menentang dan mau menang sendiri pada masa SD awal hingga SMU luput dari pengamatan. Subjek sendiri tidak membuka permasalahan tersebut pada masaitu.

Gagap yang diderita subjek berasal dari ketidaklancaran alami yang tidak berhasil diatasi. Hal ini mengakibatkan perkembangan fonologis terganggu dan kesalahan motor wicara pun menjadi-jadi. Keparahan ini ditandai dengan munculnya pengalaman awal berupa hilangnya kontrol selama proses berbicara, berlanjut ke pengalaman peristiwa traumatik yang dialami subjek. Hal ini berlanjut melalui konsolidasi pengkondisian tahun-tahun remaja dan masa-masa dewasa (Dodge, 2003). Gagap kronis tersebut terjadi karena hipoaktivitas kortikal pada hemisfer kiri sebagai respon reaktif yang dipicu oleh amigdala dan lingkaran papez. Untuk tujuan pencegahan selama wicara situasi yang signifikan ditandai secara khusus, guna mengantisipasi kesulitan wicara.

Sejalan dengan hipotesis Kagan, 
gagap subjek dipengaruhi oleh reaksi ketidaknyamanan dan pengalaman asing. Subjek mereaksinya dengan mengaktivasi sistem limbik, yakni bagian otak yang memediasi emosi dan perilaku. Aktivasi yang berlebihan menyebabkan respon di luar kesanggupan tubuh, termasuk peningkatan tekanan otot, khususnya otot laring. Perspektif ini menunjukkan bahwa lingkaran limbik mungkin merespon rasa takut dan frustasi dengan kontraksi otot-otot yang memproduksi ketegangan dan kebisuan (Dodge, 2003).

\section{Kesimpulan dan Saran}

Gagap yang diderita subjek digolongkan sebagai gagap kronis. Karakteristik linguistik yang muncul berupa frekuensi ketidaklancaran berbicara di atas $10 \%$ dalam wawancara dan berbicara bebas dan wujud kegagapan yang beragam meliputi repetisi vokal dan konsonan, suku kata, dan kata, serta prolongasi vokal dan konsonan, interjeksi, dan bloking. Karakteristik nonlinguistik yang ditemukan adalah munculnya gejala fisik seperti kekejangan pada otot mulut, getaran bibir, gerakan-gerakan bantu tangan, kernyit muka, keterbeliakan dan pejaman mata, dan gejala psikis seperti ketegangan selama wawancara dan bercerita, rasa takut salah, malu, dan gelisah. Kegagapan subjek berlangsung dalam empat fase usia.

Kegagapan pada subjek bermula dari gagap kategori primer, yakni gangguan irama yang menyertai proses perkembangan bicara, yang menjadi parah setelah tugas belajar berbahasa kedua (membaca, berbicara) gagal dilakukan pada usia 5 tahun. Tekanan lingkungan dan ketidaktepatan terapi yang berlangsung selama bertahun-tahun mengakibatkan gagap subjek tumbuh menjadi gagap sekunder, kronis, dan menetap.

Penelitian ini memberi informasi yang berharga bahwa tugas berbahasa dengan pendekatan akademik dapat berdampak serius. Oleh karena itu, perlu dikaji kembali model "pembelajaran" bahasa pada anak usia dini yang selama ini diterapkan.

Selain itu, gagap merupakan bagian dari fenomena ketidaklancaran berbicara. Oleh karena itu, perlu dikaji pula ketidaklancaran berbicara lain, baik yang dapat dikategorikan sebagai kekeliruan bicara seperti gugup, salah ucap, maupun yang dapat dikategorikan sebagai gangguan berbicara seperti afasia, cluttering, slurring, dan lisping. Pengkajian secara menyeluruh dapat memperjelas kedudukan masing-masing ketidaklancaran wicara tersebut dalam teori psikolinguistik.

\section{Daftar Pustaka}

Adam, Martin R.. 2002. "Stuttering". http://asha.org/speech/disabilit ies.cfm.

Ballenger, John Jacob. 1994. Penyakit Telinga, Hidung, Tenggorok, Kepala dan Leher. (alih bahasa: Staf Pengajar Fakultas Kedokteran UIRSCM). Jakarta : Binarupa Aksara. (hal. 785-832).

Bakwin, Harry \& Bakwin, Ruth Morris.1972. Behaviour Disorders in Children. Philadelphia : W.B. Saunders Company. (hal.399 407)

Clark, Herbert H. \& Clark, Eve V. 1977.Psychology and Language : An Introduction to Psycholinguistics. New York : Harcourt Brace Jovanovich, Publishers.

Dodge, Darell.2002. "Images of the 
Stuttering "Self". http://telosnet.com/dmdodge/ veils

Dodge, Darell.2002. A. "Reaction Inhibition Model of Stuttering Development \& Behaviour:A Neurolpsychological Theory Based on Recent Research" Colorado http://telosnet.com/dmdodge.

Garnham, Alan. 1985. Psycholinguistics : Central Topics. London: Methuen.

Hall, Nancy E. 2003. "Treating Coexisting Stuttering, Language, and Phonology Disorders" . Memphis, TN : Stuttering Foundation of America

Hallahan, Daniel P. \& Kauffman, James M.1988. Exceptional Children : Introduction to Special Education. London: Prentice-Hall International (UK) (hal.215-225)

Heins, Marilyn. 2003. "Stuttering". http:/www, parentkidsright.com .

Hurlock, Elizabeth B. 1997. Perkembangan Anak (terj. Meitasari Tjandrasa \& Muslichah Zarkasih). Jakarta:Penerbit Erlangga.

Hwang, Kyu-won. 2002. "Psychological Essay on Stuttering". http://www.shopzone.co.nz/sp eakeeasy/special.shhtm\#CANTE R JennyBay. 1996. "Stuttering". http://www.uta.edu/Hypernew s/gat/delgua/html.
Moleong, Lexy J. 2002. Metodologi Penelitian Kualitatif. Bandung : PT Remaja Rosda Karya.

Muhadjir, Noeng. 1991. Metodologi Penelitian Kualitatif. Yogyakarta: RakeSarakin.

Mussen, Paul Henry; Conger, John Janeway; Kagan, Jerome; Huston, Aletha Carol. 1988. Perkembangan dan Kepribadian Anak. (terj. Meitasari Tjandrasa). Jakarta: Penerbit Erlangga.

Shine, Richard. 1997. "Parents and Professionals can Help the Stuttering Child". Dalam Medical Journal for Doctors and Their Patiens. North Carolina.

Sudaryanto. 1993. Metode dan Teknik Analisis Data: Pengantar Penelitian Wahana Kebudayaan secara Linguistik. Yogyakarta: Duta Wacana University Press.

Van Riper, C. \& Erickson, R.L. 1996. Speech Correction : An Introduction to Speech Pathology and Audiology. Boston: Allyn \& Bacon.

Wexler, K.B. 1996. "Stuttering in Children and Adolescents" dalam Emergency and Office Pediatrics, Volume 9, Number 1996. 